\title{
Effects of Increasing Soil Fluoride on the Growth of Vegetation in the Vicinity of Brick Kilns: A Case Study from Rawalpindi, Pakistan
}

\author{
Rida Bano $^{1 *}$, Umer Khayyam¹, Sofia Khalid ${ }^{2}$ \\ ${ }^{1}$ Department of Development Studies, School of Social Sciences and Humanities (S3H), \\ National University of Sciences and Technology (NUST), Islamabad 44000, Pakistan \\ ${ }^{2}$ Environmental Sciences Department, Fatima Jinnah Women University (FJWU), Rawalpindi, Pakistan
}

Received: 25 August 2018

Accepted: 15 December 2018

\begin{abstract}
Increased fluoride emissions from brick kilns has affected the existence of plant species near brick kilns in Rawalpindi. For this purpose, six mesocosms in cardboard boxes were prepared, out of which two cardboard boxes were allocated as controls (no treatment given); while in four other cardboard box treatments of sodium fluoride, $\mathrm{NaF}$ was given. Fluoride concentrations of $30 \mathrm{ppm}$ and $50 \mathrm{ppm}$ were given to three different species of plants, i.e., Conyza Canadensis, Artemisia Absinthium and Cannabis Sativa. This study has evaluated the performance of different plants. The evaluation is done on several parameters such as chlorophyll level, carotenoid content and ascorbic acid. Similarly, other parameters checked are relative water content, above and below biomass, plant height, area of leaves and the number of leaves. Results showed that above- and below-ground biomass showed significant decreases in all selected species. Conyza Canadensis at $30 \mathrm{ppm}$ and $50 \mathrm{ppm}$ fluoride showed the greatest percentage reduction of leaf area with respect to control, i.e., $46.84 \%$ and $42.63 \%$, respectively. Cannabis Sativa showed the greatest reduction in chlorophyll at $30 \mathrm{ppm}$ (74.63\%) and $50 \mathrm{ppm}$ (59.73\%). While artemisia absinthium did not show a significant decrease in both chlorophyll a and chlorophyll b.
\end{abstract}

Keywords: brick kilns, fluoride emissions, sodium fluoride, growth parameters, plant species, chlorophyll

\section{Introduction}

The diversity of plant species provides significant evidence of an expression of biodiversity and genetic diversity [1]. But, unfortunately, excessive fluoride emissions from anthropogenic activities is adversely

*e-mail: banorida@gmail.com affecting their existence, as it has been found that most of the plants are very much sensitive to different fluoride levels [2]. Anthropogenic sources of fluoride include burning of coal, oil refining, and production of steel, phosphate fertilizer plants and brick-making industries [3]. It has been reported that the total amount of fluorine released into air, surface water and land in the United States of America were found to be 39, 24 and 500 tons, respectively. In Canada as well, the total amount of fluoride emitted yearly into the environment 
specifically from industrial sources was approximately in excess of 23500 tones [4]. Fluoride is reportedly considered one of the contaminants harmful to the environment produced by industries located in Pakistan [5]. Reportedly, the most common anthropogenic source affecting vegetation is brick kilns [6]. Moreover, brick kilns, which exist in South Asia, are often located inside and around cities on agricultural land and pollutants emitted from these brick kilns have been shown to directly affect the vegetation around the kilns [7]. Mean fluoride contents cannot exceed $5 \mathrm{mg} / \mathrm{kg}$ in plants grown in uncontaminated areas or with minimal anthropogenic activities. According to WHO Guidelines, minute injury could come about when plant species are exposed to around $0.2 \mathrm{mg} / \mathrm{m}^{3}$ of fluoride [8].

Therefore, fluoride emissions possess a considerable potential for biodiversity loss and, in turn, ecological damage as they are not biodegradable and have the ability to accumulate slowly in the environment [9]. Depending on the sensitivity, plants exhibit noticeable alteration, which includes biochemical changes or metabolite accumulation in plant species. An accurate mechanism by which fluoride causes damage to plants is still little understood. However, certain physiological processes are known to be markedly affected by fluoride. For example, a reduced rate of photosynthesis and a gradual decrease in plant growth has been reported [10]. When there will be an abundant absorption of fluoride then this will lead to phytotoxicity and ultrastructural alterations in leaves, thus affecting the biochemical and physiological characteristics [11].

\section{Fluoride Pollution and Growth of Plants}

Fluoride is present in soil, water, air, and plants in different concentrations but it is not even considered essential for the normal growth of plants [12]. Most of the plants are very much sensitive to different fluoride levels. Fluoride is first taken up by plant roots and is then transported via xylematic flow of the transpiratory and storage organs. Bioaccumulation of fluoride in different parts of plants varies depending on its transfer from soil solution to roots and its movement from root to shoot [13].

Plants show more susceptibility to fluoride injury from the soil than the atmosphere [14]. Arya (1971) reported the worst injury to tomato plants when fluoride entered through the roots when a $250 \mathrm{ppm}$ concentration of sodium fluoride solution was supplied [15]. Stevens et al. (1997) in their study revealed that fluoride ions in solution had a noticeable influence on the uptake of fluoride by plant roots, with complex species being more readily taken up by the roots than the free fluoride ions [16].

\section{Fluoride Pollution and Pakistan}

Ahmad et al. (2012) have highlighted the unfavourable effects of fluoride on vegetation as an evolving and unrecognized problem in South Asia. This is due to population growth and more construction, which is increasing the demand for bricks [17]. It is reported that $75 \%$ of the total global brick kilns (approx. $300,000)$ are located in countries including Pakistan, stand with 11000 brick kilns - most of which are located in Punjab Province, where the study area is located [18]. Like Pakistan, brick kilns in the South Asian region emit pollutants upon consuming 'coal' as an energy source that ultimately affects vegetation cover in the vicinity [19].

Therefore, research was conducted to study the effects of excessive emissions of fluoride from brick kilns in Rawalpindi. The effects on plant species of fluoride emissions from brick kilns were analyzed by the following parameters: 1) growth attributes, which include leaf area, number of leaves and plant height; 2) biochemical changes by examining the change in ascorbic acid, carotenoid content, chlorophyll level and relative water content; and 3) changes in above- and below-ground biomass of each of the selected plant species.

\section{Materials and Methods}

\section{Overview of Study Area and Selected Species}

The study was carried-out around a brick kiln site in Rawalpindi, Pakistan, which has a semi-arid sub-tropical climatic zone and experiences great variations in temperature. The annual temperature of Rawalpindi is $21.5^{\circ} \mathrm{C}$ and annual rainfall is $941 \mathrm{~mm}$ [20]. Compared to the rest of the country, Rawalpindi remains most appropriate for the study as it is among the older cities in the country and therefore is a hub of industrial and commercial works [21]. In the initial phase of the study, brick kiln sites of Rawalpindi were visited and then plant species were selected on the basis of their common presence around brick kilns. Subsequently, the research study targeted the plant species, namely Cannabis Sativus, Conyza Canadensis and Artemisia Absinthium - commonly grown wild species around brick kilns in the study area. The presence of selected species cannot be ignored as they are commonly present around almost all the brick kiln sites of Rawalpindi (study area). So, it was necessary to check the effects of fluoride only on selected species which, actually, have a habitat along brick kiln sites. Each of the variety of species has its own significance for different purposes, too. For example, Conyza Canadensis has a property of reducing blood glucose levels and simultaneously improving glucose tolerance and hence is taken as a cure for diabetes [22]. Similarly, Cannabis Sativus and Artemisia Absinthium both are associated with a cure for different types of cancers [23-24]. 


\section{Preparing Mesocosms and Collecting Seedlings of Selected Species}

Soil $\mathrm{pH}$ affects the soil's physical, chemical, and biological properties and processes, as well as plant growth. The $\mathrm{pH}$ of the soil in the mesocosms of the current study was 7.2. The normal $\mathrm{pH}$ range for productive soil is from 6.5 to 8.4 [25]. The $\mathrm{pH}$ values of these soils indicate that the study areas have the required range for plant growth. The electrical conductivity of the soil in the mesocosms at the start of the experiment was found to be $0.108 \mathrm{dS} / \mathrm{m}$, where different species of plants were grown, which means that conductivity value of the analyzed soil in this research work was within the normal range, i.e., $0-2 \mathrm{dS} / \mathrm{m}$ as reported by Zaku et al. in their research [26]. EC value of the soil in the mesocosms is an indication of nonsalinity. As high EC serves as a sign of salinity $(\mathrm{EC}>4 \mathrm{dS} / \mathrm{m})$, which delays crop growth (inability to absorb water) and microbial activity [27].

For the purposes of data and processing, six mesocosms in total were prepared in $35.6 \mathrm{~cm}$ x $19.8 \mathrm{~cm}$ cardboard boxes. These mesocosms were filled with soil from the study site. Further, seedlings of Cannabis Sativus, Conyza Canadensis and Artemisia Absinthium, which were similar in size and at the same growth stage were collected and transferred into the prepared boxes. In each box, two seedlings of each species were planted. Two boxes were used as a control where no treatment was given. Similarly, two boxes were used for each treatment of fluoride, i.e., $30 \mathrm{ppm}$ and $50 \mathrm{ppm}$ of sodium fluoride $(\mathrm{NaF})$. These levels of concentration of $\mathrm{NaF}$ have been selected in accordance with the previous studies conducted on the growth parameters of different plants, i.e., Raphanus Sativus and Abelmoschus Esculentus [28-29].

\section{Preparation of Stock Solution and Treatment of Sodium Fluoride (NaF)}

For treatment of $\mathrm{NaF}, 1000$ ppm stock solution of sodium fluoride was prepared by dissolving $2.21 \mathrm{~g}$ of sodium fluoride in $1000 \mathrm{ML}$ of distilled water'. By using this stock solution of $1000 \mathrm{ppm}$, two different dilutions of 30 and $50 \mathrm{ppm}$ were prepared. Later, first treatment was given when the seedlings of each species attained stability and a certain height. Other two treatments were given with an interval of one week in order to check the effects of fluoride on plant growth patterns. So for the total period of six weeks, these mesocosms have been incubated under greenhouse conditions at a temperature of between 17 and $23^{\circ} \mathrm{C}$ and relative humidity between $55 \%$ and $85 \%$, and a $14 \mathrm{~h}$ photoperiod. Similarly, with distilled water (for quality

12.21 g Calculation:-

Molar mass of NaF: $41.98817 \mathrm{~g} / \mathrm{mol}$

Divide the total weight by atomic mass of fluorine gave $2.21 \mathrm{~g}$ $41.987 / 18.998=2.21$ control) plant species were watered regularly until harvesting.

\section{Procedures for Determining Selected Parameters}

\section{Measurement of Growth Attributes}

The first parameter was the measurement of 'growth attributes,' which include leaf area, number of leaves and plant height. Area of the leaf was measured by using the graphical method and after every treatment one leaf (from each treated plant species) was removed and placed on the graph. On the graph, number of square centimeters were counted. [30]. Then, the number of leaves was counted for each species and noted. Lastly, heights of plants were also measured by a commonly used procedure, i.e., measuring the height with tape from the base to the tip of the last leaf [31].

\section{Determining Biochemical Changes}

The second parameter is determining 'biochemical change,' which includes change in ascorbic acid, carotenoid content, chlorophyll levels and relative water content (RWC). Initially, 'Chlorophyll a, b, total chlorophyll' level and 'carotenoid content' were determined by using the Arnon method (1949) [32]. For this purpose, fresh leaves weighing $0.5 \mathrm{~g}$ were cut down and crushed with $10 \mathrm{ml}$ of $80 \%$ acetone. Then the extract was centrifuged at $2500 \mathrm{rpm}$ for 10 minutes. Absorbance of leaf extract was measured through an ultraviolet (UV) spectrophotometer and recorded at wavelengths of $645 \mathrm{~nm}, 663 \mathrm{~nm}$ and $480 \mathrm{~nm}$. The estimated chlorophyll levels were calculated through Arnon equations (1949) as:

$$
\begin{aligned}
& \text { Chlorophyll } \mathrm{a}=0.0127 \times \mathrm{A} 663-0.00269 \times \mathrm{A} 645 \\
& \text { Chlorophyll } \mathrm{b}=0.0229 \times \mathrm{A} 645-0.00468 \times \mathrm{A} 663
\end{aligned}
$$

Total Chlorophyll $=0.0202 \times \mathrm{A} 645+0.00802 \times \mathrm{A} 663$

Then, the 'carotenoid content' was exclusively determined using the formula presented by Kirk and Allen (1965) [33]:

$$
\begin{gathered}
\text { Carotenoid }(\mathrm{mg} / \mathrm{g})=\mathrm{A} .480+(0.114 \\
\text { x A.663-0.638 x A.645) }
\end{gathered}
$$

...where A 645, 638, 663 and 480 is absorbance at 645, 638, 663 and 480, respectively.

Ascorbic acid was determined by the titration method in which $2 \mathrm{mg}$ of leaf sample was ground with $5 \%$ metaphosphoric acid. This sample was crushed with mortar and pestle until a slurry was formed. Then filtration was done through Whatman filter paper. And $10 \mathrm{ml}$ of filtrate was titrated against the recommended 
DCIP dye [34]. When the color was changed into pink then the volume of DCIP dye was noted. The DCIP solution was standardized against the known quantity of ascorbic acid. This was achieved by the titration of DCIP solution into a solution containing $1 \mathrm{ml}$ ascorbic acid and $9 \mathrm{ml}$ of $5 \%$ of metaphosphoric acid. The endpoint of this titration was the conversion into pink color that was seen after only 15 seconds. The complete calculation method for determining an ascorbic acid is to divide $4.0 \mathrm{mg}$ (the amount of ascorbic acid present in the standard solution) by the number of $\mathrm{ml}$ of dye titrated to determine the amount of ascorbic acid equivalent to $1.0 \mathrm{ml}$ of dye:

$$
\frac{\text { Ascorbic acid }(\mathrm{mg})}{1.0 \mathrm{ml} \text { of dye }}=\frac{4.0 \mathrm{mg} \text { of Ascorbic acid }}{\text { DCIP titrated }(\mathrm{ml})}
$$

For the determination of ascorbic acid in and an aliquot of extract:

$$
\frac{\text { Ascorbic acid (mg) }}{\text { Aliquot }}=\text { DCIP Titrated x Answer (1) (2) }
$$

Ascorbic acid $\mathrm{mg} / \mathrm{g}=$

$$
\frac{\text { Answer of equation (2) x Total volume of extract }}{\text { Volume of aliquot }}
$$

Then, lastly under biochemical change, the relative water content of selected species of plants was determined through the following formula derived by Chen and his colleagues [35]:

$$
\begin{aligned}
& \begin{array}{c}
\text { Relative water content } \%= \\
\text { Fresh Weight }- \text { Dry weight } \\
\text { Fresh weight }
\end{array} \text {. } 100
\end{aligned}
$$

\section{Determining above- and below-Ground Biomass}

The third and last parameter in the study was the determination of 'biomass' both above and below ground, for each species, at the end of experiment. For that purpose, destructive harvest was carried out at both above and below ground against all biomass species. Here, fresh biomass was determined just after harvesting. For determination of dry biomass, plants were dried in an oven for 48 hours at $65^{\circ} \mathrm{C}$ and then weight was determined on a balance [36].

\section{Statistical Analysis}

All parameters' means were calculated and analysis of variance (ANOVA) was performed by using statistical package SPSS V. 21 to check significant differences between treatments. While for biomass and relative water content, the data was calculated in percentages reduction with respect to control.

\section{Results and Discussion}

\author{
Effects of the Treatment of $\mathrm{NaF}$ \\ on Leaf Area
}

The results of the present study showed that in controlled plants the area of leaf was more than the treated plants, which were given $30 \mathrm{ppm}$ and $50 \mathrm{ppm}$ of sodium fluoride as shown in Fig. 1. Percentage reduction with respect to controlled plants was noticed in treated plants.

The percentage reductions in Conyza Candensis at 30 and $50 \mathrm{ppm}$ were found to be $46.84 \%$ and $42.63 \%$. While Artemisia Absinthium at both the concentrations of $30 \mathrm{ppm}$ and $50 \mathrm{ppm}$ of sodium fluoride showed a percentage reduction of $7.69 \%$. The percentage reductions in Cannabis Sativus at 30 and $50 \mathrm{ppm}$ of sodium fluoride were found to be $17.65 \%$ and $11.76 \%$.

When the different concentrations of fluoride were analyzed, the result was not found to be significant (Cannabis sativus p-value $=0.60$ and $\mathrm{F}=0.55$, Artemisia Absinthium p-value $=0.37$ and $\mathrm{F}=1.1$ Conyza Canadensis $\mathrm{p}=0.1$ and $\mathrm{F}=2.6$ ). The trend of percentage reduction in all the selected plant species are in accordance with the study conducted on Hypericum Perforatum plants. Most interestingly, it was found that percentage reduction in $50 \mathrm{ppm}$ was less than the percentage reduction in $30 \mathrm{ppm}$. These results are in accordance with the results of the study conducted on Triticum Aestivum [37-38].

\section{Effects of the Treatment of $\mathrm{NaF}$ on Number of Leaves}

The percentage reduction seen in Conyza candensis was $23 \%$ at $50 \mathrm{ppm}$ of $\mathrm{NaF}$, whereas there was not any marked percentage reduction seen in Conyza candensis at $30 \mathrm{ppm}$ of sodium fluoride. Artemisisa absinthium did not show any reduction in the number of leaves at both $30 \mathrm{ppm}$ and $50 \mathrm{ppm}$ concentrations of $\mathrm{NaF}$, whereas Cannabis sativa showed a decrease in number of leaves and percentage reduction was found to be $15 \%$ at both the concentration of $30 \mathrm{ppm}$ and $50 \mathrm{ppm}$ of sodium fluoride (shown in Fig. 2). These mentioned results are in accordance with the study of Singh et al. (2013) on growth parameters of Raphanus Sativus L., which

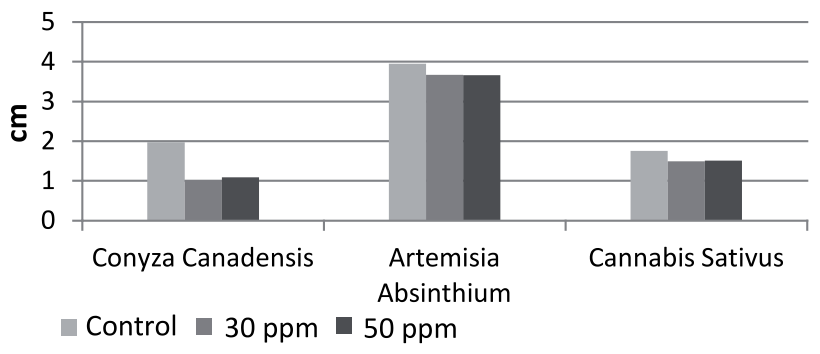

Fig. 1. Mean leaf area of Conyza Canadensis, Artemisia Absinthium and Cannabis Sativus. 


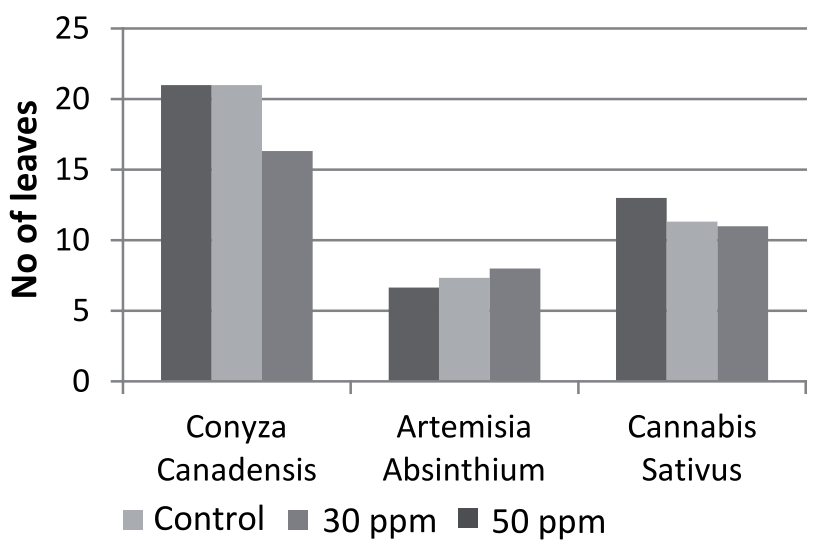

Fig. 2. Mean of number of leaves of Conyza Canadensis, Artemisia Absinthium and Cannabis Sativus.

revealed that treated plants with a range of sodium fluoride $(\mathrm{NaF})$ also showed a reduction in number of leaves [39]. The differences between concentrations were analyzed in each species, but the results were not significant as the p-values of Conyza Canadensis, Cannabis Sativus and Artemisia Absinthium were $0.7313,0.0955$ and 0.3944 , respectively.

\section{Effects of the Treatment of $\mathrm{NaF}$ on Plant Height}

The results of the present study showed that with increasing fluoride level, the heights of the plants decreased as shown in Fig. 3 below, whereas Artemisia Absinthium had not shown a percentage reduction in height during the experiment with respect to control plants. But it was noticed that the rate of growth was slowed after treatments were given. This behaviour of Artemisia Absinthium of increased height and diameter has also been seen in another study conducted by Papafotiou and colleagues [40]. While other species, i.e., Conyza Canadensis (percentage reduction of 7\% at $30 \mathrm{ppm}$ and $21 \%$ at $50 \mathrm{ppm}$ ) and Cannabis Sativus (percentage reduction of $26.92 \%$ at $30 \mathrm{ppm}$ and $15.38 \%$ at $50 \mathrm{ppm}$ ) showed a reduction in heights with respect to control. The results of the study are consistent with the results of Singh et al. (2013). The results of different

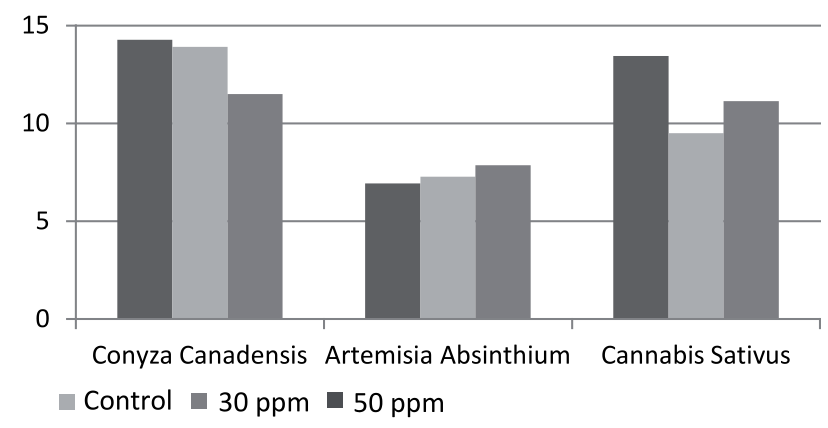

Fig. 3. Mean plant heights of Conyza Canadensis, Artemisia Absinthium and Cannabis sativus. concentrations of fluoride were not found to significant (Conyza Canadensis, value of $\mathrm{p}=0.18 \mathrm{~F}=2.12$, Cannabis sativus value of $p=0.13 \mathrm{~F}=2.8$, Artemisia Absinthium value of $p=0.4 \mathrm{~F}=0.9$ ) when analyzed. It was noticed that the heights of the treated plants were growing slowly as compared to the controlled plants, and this pattern of growth is in accordance with the above-mentioned studies.

\section{Effects of the Treatment of NaF on Chlorophyll a, b and Total Chlorophyll}

At 30 and $50 \mathrm{ppm}$ concentrations of sodium fluoride in the current study, Conyza Canadensis showed a decrease in chlorophyll of about $62.5 \%$ and $55.5 \%$, respectively. Whereas at 30 and $50 \mathrm{ppm}$, chlorophyll b showed a percentage decrease with respect to control of $59.26 \%$ and 26\% respectively (as can be seen in Fig. 5). It was noticed only in the middle of the second week that Conyza Canadensis at both $30 \mathrm{ppm}$ and $50 \mathrm{ppm}$ showed a value of an increasing trend in chlorophyll a concentration, after which transformation occurred into persistent decreasing values until the end of the experiment. Results showed that Artemisia Absinthium at $30 \mathrm{ppm}$ and $50 \mathrm{ppm}$ of sodium fluoride showed a decrease in the level of chlorophyll ' $a$ ' of about $53.85 \%$ and $32.69 \%$ respectively. But, in the case of chlorophyll b, it was seen that there was an increase in chlorophyll b level at 30 and $50 \mathrm{ppm}$ as shown in Fig. 5. In the case of Cannabis Sativa, in the controlled condition, it showed an increase in chlorophyll level. But at $30 \mathrm{ppm}$ and $50 \mathrm{ppm}$, chlorophyll a decreased about $74.63 \%$ and $59.7 \%$ with respect to control. Similarly, Chlorophyll b at 30 and $50 \mathrm{ppm}$ showed a decrease of about $64.7 \%$ and $47 \%$ respectively in Cannabis Sativa. Total chlorophyll content of Cannabis Sativus, Conyza Canadensis and Artemisia Absinthium had an overall decreasing trend with the passage of time, as shown in Fig. 6.

The differences between concentrations were analyzed in each species. We found that in Conyza Canadensis there was a significant decrease in chlorophyll a $(\mathrm{p}=0.02, \mathrm{~F}=6.0143$, Std. deviation for control, 30 and $50 \mathrm{ppm}$ were found to be $0.204,0.025$ and 0.153 respectively) and chlorophyll $\mathrm{b}(\mathrm{p}=0.0369$, $\mathrm{F}=6.0143$, Std. deviation for control, 30 and $50 \mathrm{ppm}$ were found to be $0.042,0.066$ and 0.101 respectively). Similar results have been seen in Cannabis Sativus (for chlorophyll a, value of $\mathrm{p}=0.0038 \mathrm{~F}=16.2181$, Std. deviation for control $=0.178,30 \mathrm{ppm}=0.067$ and $50 \mathrm{ppm}=0.051$ while for chlorophyll $\mathrm{b}$ value of $\mathrm{p}=0.007 \mathrm{~F}=12.4688$, Std. deviation for control $=0.060$ $30 \mathrm{ppm}=0.015$ and $50 \mathrm{ppm}=0.021$ ), whereas Artemisia Absinthium did not show a significant decrease when it was analyzed at different concentrations. Results from the present study are in agreement with the study of Sreedevi and Damodharam, (2013) in which chlorophyll a, chlorophyll b, and total chlorophyll content in leaves of Cicer aritinum decreased at $75 \mathrm{ppm}$ of sodium fluoride 
[41]. The reason for this reduction of chlorophyll content in the current study may be due to the breakdown of chlorophyll molecule during stress. Another reason can be inhibition of biosynthesis of chlorophyll, which is a major symptom of chlorosis induced by fluoride [42].

\section{Effects of the Treatment of $\mathrm{NaF}$ on Carotenoid Content}

Carotenoids are accessory pigments in photosynthetic systems and protect chlorophyll against oxidative stress [43]. Similarly, in the present work carotenoid content was found to be decreasing at the concentration of $30 \mathrm{ppm}$ and $50 \mathrm{ppm}$ of sodium fluoride. But, it has been

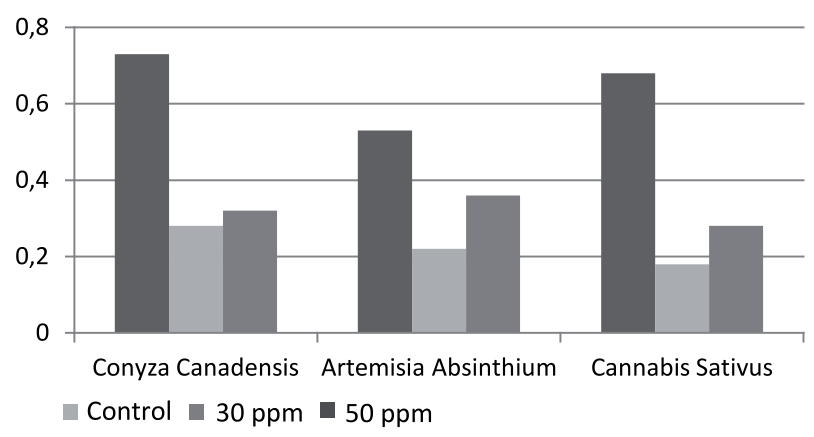

Fig. 4. Mean chlorophyll a concentration in Conyza Canadensis, Artemisia absinthium and Cannabis sativus.

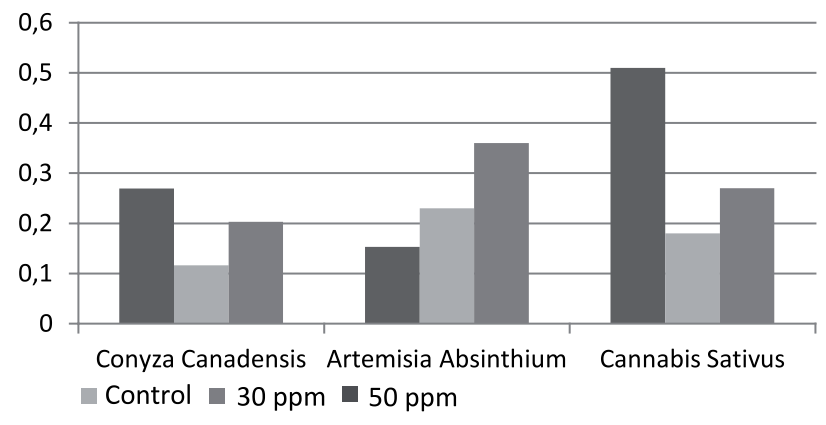

Fig. 5. Mean of chlorophyll b concentration in Conyza Canadensis, Artemisia Absinthium and Cannabis Sativus.

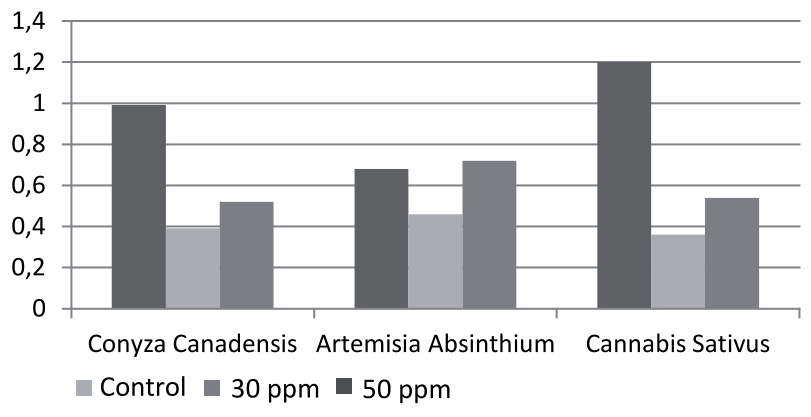

Fig. 6. Mean of total chlorophyll of Conyza Canadensis, Artemisia Absinthium and Cannabis Sativus.

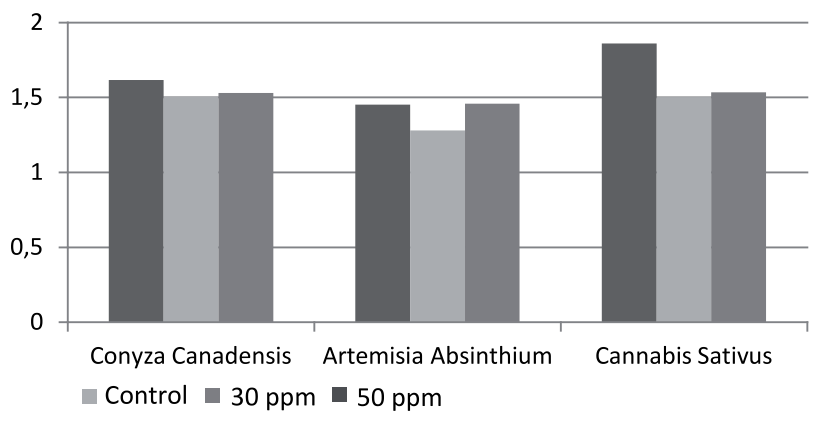

Fig. 7. Mean carotenoid concentrations in Conyza Canadensis, Artemisia Absinthium and Cannabis Sativus.

seen at the same time that carotenoid content increased in the initial weeks with the growth of plants. The percentage reduction in Conyza Candensis, Artemisia Absinthium, and Cannabis Sativus were found to be $6.5 \%, 14.29 \%$ and $16.67 \%$ in both 30 and $50 \mathrm{ppm}$ of sodium fluoride. Whereas it was revealed that Artemisia Absinthium had not shown any reduction, in carotenoid content at $50 \mathrm{ppm}$ of $\mathrm{NaF}$, as shown in Fig. 7. There was no significant reduction found in the result when different concentrations of fluoride were analyzed in each species. As the value of $\mathrm{p}$ of Conyza Canadesis, Artemisisa Absinthium and Cannabis Sativus was found to be greater than 0.05 , i.e., $0.83,0.85$ and 0.50 respectively.

Our results are in accordance with the study on Oryza Sativa L. to fluoride stress, which was carried out by [44]. In their results, the carotenoid content decreased by up to $50 \%$ of the controlled species. As carotenoid content prevents the production of single oxygen by inhibiting the excited states of chlorophyll molecule and this condition maybe due to the fluoride toxicity which affects carotenoid content.

\section{Effects of the Treatment of $\mathrm{NaF}$ on Ascorbic Acid}

Ascorbic acid is an antioxidant that plays an important role in protecting against physiological stress. There is a rapid increase in ascorbic acid when there is some salt stress on plants. Thus this increase indicates that ascorbic acid is involved in many physiological processes, but there have been a lot of differences in views regarding the mechanisms through which ascorbic acid reduces the damaging effects of such stresses in plants [45]. Similar results of increasing ascorbic acid have been seen in the present study, where the percentage increase was noticed with respect to control (as can be seen in Fig. 8 below). At 30 ppm, Conyza Canadensis showed a percentage increase of $24.41 \%$ and Cannabis Sativus showed a percentage increase of $27 \%$ with respect to control. A similar increasing trend of ascorbic acid followed when $50 \mathrm{ppm}$ of sodium fluoride was also given. But in Artemisia Absinthium ascorbic acid increased only when $50 \mathrm{ppm}$ of sodium fluoride was 


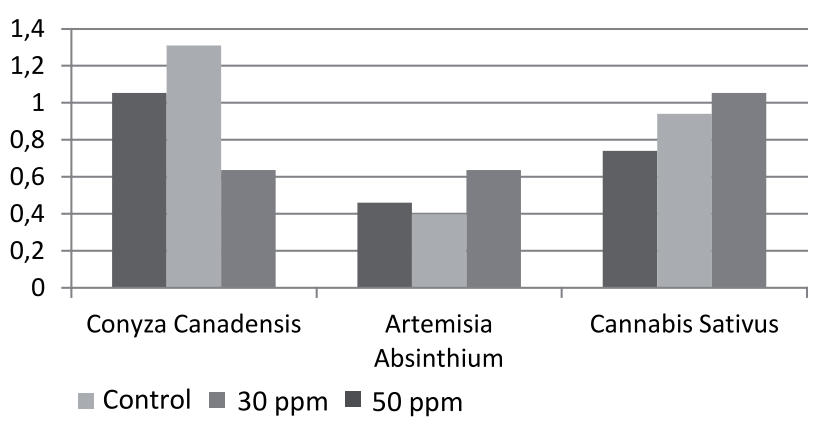

Fig. 8. Mean ascorbic acid concentrations in Conyza Canadensis, Artemisia Absinthium and Cannabis Sativus.

provided to them and there was not as much increase in $30 \mathrm{ppm}$ of NaF, whereas Conyza Canadensis at $50 \mathrm{ppm}$ of sodium fluoride did not show an increase in ascorbic acid, but a visible injury in leaves was seen during the experiment. The differences between concentrations of fluoride were analyzed in each species and the results were not found to be significant in all three species (Conyza Canadensis, value of $\mathrm{p}=0.1 \mathrm{~F}=3.36$, Cannabis Sativus value of $p=0.3 \mathrm{~F}=1.0$, Artemisia Absinthium value of $p=0.16 \mathrm{~F}=1.4$ ) at all concentrations.

\section{Effects of the Treatment of NaF on Relative Water Content (RWC)}

RWC of a leaf is the presence of water relative to its turgidity. Water is a requirement for plant life. A high level of water content in a plant body will assist in the maintenance of physiological balance under harsh conditions such as fluoride toxicity stress when the transpiration rates are usually high. Plants with high relative water content under polluted conditions may be tolerant of pollutants [46]. The results of the present study showed that with increasing fluoride content, the relative water content increased. In controlled conditions, Cannabis Sativus, Conyza Canadensis and Artemisia Absinthium had a relative water content of $20 \%, 16 \%$, and $10 \%$ respectively. At 30 and $50 \mathrm{ppm}$, Cannabis Sativa showed an increasing trend of $25 \%$ and $27 \%$ respectively. While Conyza Canadensis at 30 and $50 \mathrm{ppm}$ of sodium fluoride showed an increasing trend of $25 \%$ and $58.6 \%$ respectively. Similarly, Artemisia Absinthium at 30 and $50 \mathrm{ppm}$ showed an increasing trend of $11 \%$ and $23 \%$ respectively.

A similar trend has been shown by below-ground biomass, where the relative water content in treated plants was found to be greater than controlled plants. This increased trend has also been seen in the study conducted on Olea Europaea $L$. The reason for increased relative water content is stated that high accumulation of proline and soluble sugars plays a role in the activation of water uptake to maintain cellular tissue turgor [47-48]. Some other studies have revealed that at higher concentrations above relative water content of plants decreased [49].

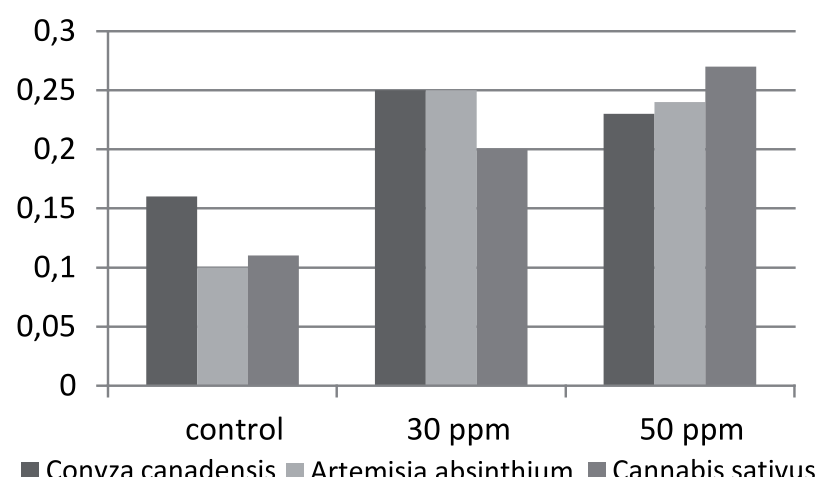

Fig. 9. Relative water content of aboveground biomass.

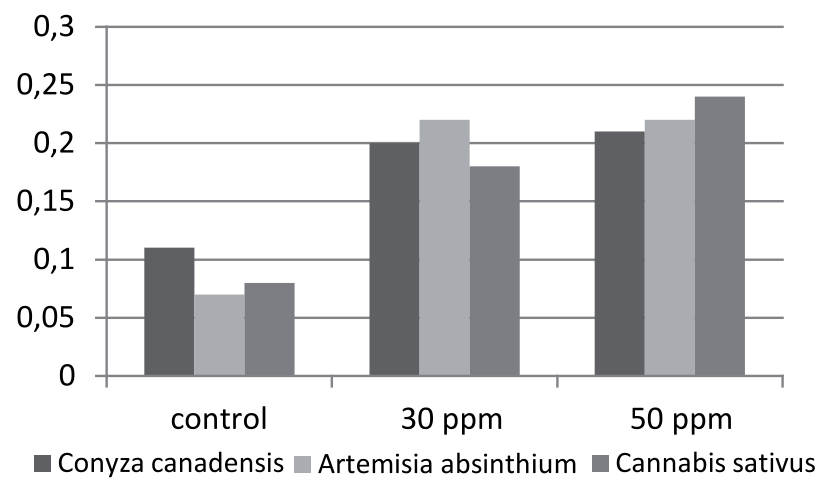

Fig. 10. Relative water content of belowground biomass.

Effect of the Treatment of NaF on Biomass

\section{Fresh Weight (above and below Biomass of Treated Species)}

The present study showed that there had been a reduction in the above- and belowground biomass of treated species. Control and treated plants were more or less similar, but as the treatment progressed then reductions in the biomass of Brassica Napus L. were seen. However, a significant reduction in fresh weight of root, shoot, and leaf was recorded with respect to control [50]. Similarly, in the present study, it was noticed that there was more reduction in the aboveground biomass than the belowground biomass of Conyza Candensis, Artemisisa Absinthium, and Cannabis Satavis. Mentioned reductions in studies are implied to be due to the fact that fluoride causes a reduction in root length and shoot length due to unbalanced nutrient uptake by seedlings in the presence of fluoride. The results of our study showed that treated plants with 30 and $50 \mathrm{ppm}$ concentrations of sodium fluoride had a decrease in fresh and dry weight in aboveground biomass. At a $30 \mathrm{ppm}$ concentration of sodium fluoride, aboveground biomass of Cannabis sativa was reduced by $23.4 \%$. While at $50 \mathrm{ppm}$ concentration of sodium fluoride there was a reduction of $29.63 \%$ of aboveground biomass of Cannabis sativa. Similarly, Conyza Canadensis at $30 \mathrm{ppm}$ and $50 \mathrm{ppm}$ concentrations of sodium fluoride 


\section{Aboveground}

Biomass

Conyza Canadensis

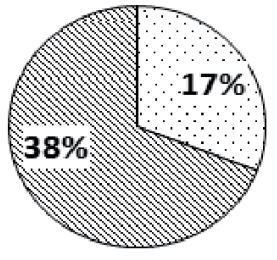

Artemisia Absinthium
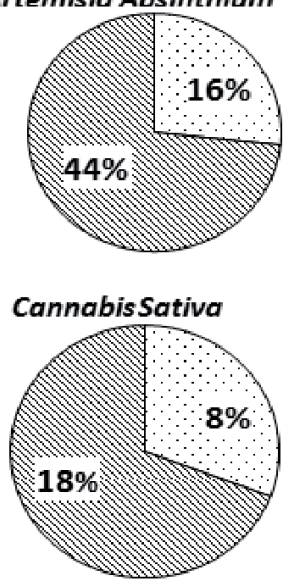

Belowground Biomass

\section{Conyza Canadensis}

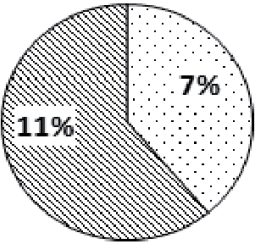

Artemisia Absinthium

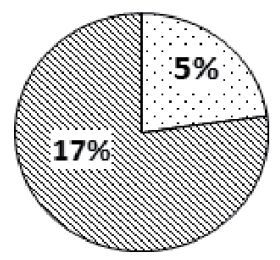

Cannabis Sativa

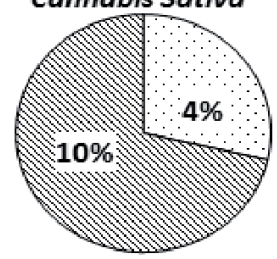

$\square \mathbf{3 0} \mathbf{p p m} \otimes \mathbf{5 0} \mathbf{p p m}$
Fig. 11. Fresh weights of above- and belowground biomass.

\section{Aboveground \\ Biomass}

\section{Artemisia Absinthium}

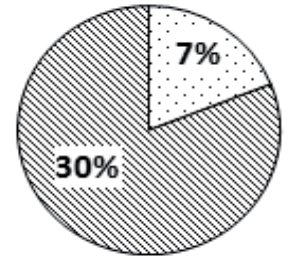

Conyza Canadensis

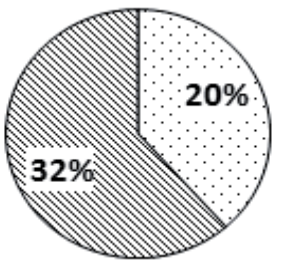

Cannabis Sativa

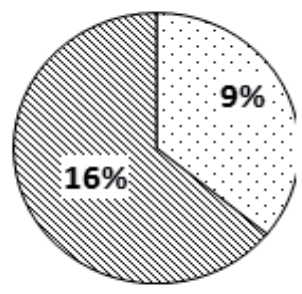

Belowground Biomass

Artemisia Absinthium

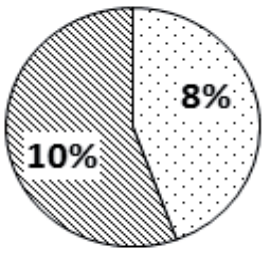

Conyza Canadensis

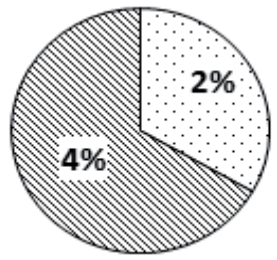

Cannabis Sativa

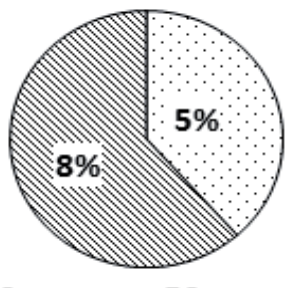

showed a reduction of $23.3 \%$ and $57.58 \%$ of fresh aboveground biomass respectively. While Artemisia Absinthium at $30 \mathrm{ppm}$ and $50 \mathrm{ppm}$ concentrations of sodium fluoride showed a reduction of $11.64 \%$ and $21.19 \%$ respectively.

\section{Dry Weight of above- and below- Ground Biomass}

Likewise, the results of aboveground biomass; it also showed that treated plants have a decrease in fresh and dry weight in belowground biomass as well. At $30 \mathrm{ppm}$ concentration of sodium fluoride, belowground biomass of Cannabis Sativa was reduced by $25 \%$, while at $50 \mathrm{ppm}$ concentrations of sodium fluoride there was a reduction of $33.7 \%$ in belowground biomass of Cannabis Sativa. Similarly, Conyza Canadensis at $30 \mathrm{ppm}$ and $50 \mathrm{ppm}$, the concentration of sodium fluoride, showed a reduction of $16.67 \%$ and $25 \%$ respectively, while Artemisia Absinthium at $30 \mathrm{ppm}$ and $50 \mathrm{ppm}$ concentrations of sodium fluoride showed reductions of $33.33 \%$ and $40 \%$, respectively.

\section{Conclusions}

We studied and evaluated the effects of different concentrations of fluoride in wild plants that are common near brick kilns. Under fluoride toxicity, we have found that $50 \mathrm{ppm}$ and $30 \mathrm{ppm}$ concentrations of fluoride, given three times within an interval of a week, affected different growth attributes of selected plants such as area of leaves, heights of plant, carotenoid content, and chlorophyll level. Whereas untreated plants have grown healthy, which shows that increasing fluoride levels in the environment are affecting the plant's species - especially those which are near brick kilns. Overall, this study suggests that in $30 \mathrm{ppm}$ of fluoride (given three times with an interval of a week), plants can still grow, but above this range major physical as well as chemical changes can be observed in those affected plants.

\section{Acknowledgements}

The authors of this study are grateful to the journal editor highlighting the structural changes required to improve the outlook of this manuscript. Special thanks also go to anonymous reviewers for their detailed reviews and comments that helped the authors refine the findings and results of this study presented in this manuscript.

\section{Conflict of Interest}

The authors declare no conflict of interest.

Fig. 12. Dry weight of above- and belowground biomass. 


\section{References}

1. AGBAIRE P., ESIEFARIENRHE E. Air Pollution tolerance indices (apti) of some plants around Otorogun Gas Plant in Delta State, Nigeria. Journal of Applied Sciences and Environmental Management, 13 (1), 2009.

2. SINGH S.,SINGH J., SINGH N. Studies on the impact of fluoride toxicity on growth parameters of Raphanus sativus L. Indian Journal of Scientific Research, 4 (1), 61, 2013.

3. LUCCHINI R., BENEDETTI C. Other metals. Textbook of Children's Environmental Health, 290, 2013.

4. WORLD HEALTH ORGANIZATION. Environmental health criteria, Fluorides, 227, 268, 2002.

5. PAKISTAN ECONOMIC SURVEY. Environment. Ministry of Finance, 2015. Retrieved from http://www. finance.gov.pk

6. SHAIKH S., NAFEES A.A., KHETPAL V., JAMAL A.A., ARAIN M.A., YOUSUF A. Respiratory symptoms and illnesses among brick kiln workers: a cross-sectional study from rural districts of Pakistan. BMC Public Health, 12 (1), 999, 2012.

7. SKINDER B.M., AFEEFA Q.S., PANDIT A.K., GANAI B.A. Brick kiln emissions and its environmental impact: A Review. Journal of Ecology and The Natural Environment, 6 (1), 1, 2014.

8. WORLD HEALTH ORGANIZATION. Environmental health criteria, Fluorides, 227, 268, 2002.

9. WEINSTEIN L.H., DAVISON A.W. Native plant species suitable as bio indicators and bio monitors for airborne fluoride. Environmental Pollution, 125, 3, 2003.

10. SREEDEVI R., DAMODHARAM T. Exterminate consequence of $\mathrm{NaF}$ on seed germination and some morphological changes of major pulse crop Cicer aritinum L. Cv. Anuradha (Bengal gram). Asian J. Plant Sci. Res, 3 (2), 38, 2013.

11. KUMAR K.A., VARAPRASAD P., RAO A.V.B. Effect of fluoride on catalase, guiacol peroxidase and ascorbate oxidase activities in two verities of mulberry leaves (Morus alba L.). Res J Earth Sci, 1 (2), 69, 2009.

12. WEYANT C., ATHALYE V., RAGAVAN S., RAJARATHNAM U., LALCHANDANI D., MAITHE L.S., BOND T.C. Emissions from South Asian brick production. Environmental science \& technology, 48 (11), 6477, 2014.

13. KAMALUDDIN M., ZWIAZEK J.J. Fluoride inhibits root water transport and affects leaf expansion and gas exchange in aspen (Populus tremuloides) seedlings. Physiologia Plantarum, 117 (3), 368, 2003.

14. GREWAL M.S., KUMAR A., KUHAD M.S. Spatial variation of fluorine in an Indo-Gangetic alluvial plain of India. Fluoride, 29 (3), 166, 1996.

15. ARYA K.P.S. Ecophysiological and cytogenetical response of certain crop plants to sodium fluoride and sulphur dioxide toxicity, Ph.D. Thesis, 1971. Banaras Hindu University, Varanasi (U.P.) India.

16. STEVENS D.P., MCLAUGHLIN M.J., ALSTON A.M. Phytotoxicity of aluminum-fluoride complexes and their uptake from solution culture by Avena sativa and Lycopersicon Esculentum. Plant and Soil 192, 81, 1997.

17. AHMAD M.N., VAN DEN BERG L.J., SHAH H.U., MASOOD T., BÜKER P., EMBERSON L., ASHMORE M. Hydrogen fluoride damage to vegetation from periurban brick kilns in Asia: A growing but unrecognised problem?. Environmental pollution, 162, 319, 2012.
18. CLEAN AIR TASK FORCE. Black Carbon Emissions from Brick Kilns, 2012. Retrieved from http://www.catf. us/resources/

19. WEYANT C., ATHALYE V., RAGAVAN S., RAJARATHNAM U., LALCHANDANI D., MAITHEL S., BOND T.C. Emissions from South Asian brick production. Environmental science \& technology, 48 (11), 6477, 2014.

20. AHMED S., NASEEMULLAH A.M., MOHAMMAD K., SKEIKH N.I. Gastroesophageal reflux disease masquerading as upper respiratory illness and response to treatment. J Rawalpindi Med Coll, 4, 11, 2000.

21. BUTT A., AHMAD S.S., SHABBIR R., ERUM S. GISbased surveillance of road traffic accidents (RTA) risk for Rawalpindi city: a geo-statistical approach. Kuwait Journal of Science, 44 (4), 2017.

22. ASLAM H., KHAN A.U., NAUREEN H., ALI F., ULLAH F., SADIQ A. Potential application of Conyza canadensis (L) Cronquist in the management of diabetes: In vitro and in vivo evaluation. Tropical Journal of Pharmaceutical Research, 17 (7), 1287, 2018.

23. MUGHEES M., SAMIM M., WAJID S. 83P Artemisia absinthium extract loaded polymeric nanoparticles as the therapeutic remedy for breast cancer. Annals of Oncology, 29 (30), 47, 2018.

24. BALA A., MUKHERJEE P.K., BRAGA F.C., MATSABISA M.G. Comparative inhibition of MCF7 breast cancer cell growth, invasion and angiogenesis by Cannabis sativa L. sourced from sixteen different geographic locations. South African Journal of Botany, 119, 154, 2018.

25. RAMANKUTTY N., NAVIN R., FOLEY J.A., NORMAN J., MCSWEENEY K. The global distribution of cultivable lands: current patterns and sensitivity to possible climate change. Global Ecology and Biogeography, 11 (5), 377, 2002.

26. ZAKU S.G., EMMANUEL S.A., THOMAS S.A. Assessing the level of soil nutrients: a case study of Donga, Ibi and Wukari farmlands in Taraba State, Nigeria. Agric. Biol. JN Am, 2 (1), 101, 2011.

27. UNITED STATES DEPARTMENT OF AGRICULTURE. Natural Resources Conservation Service. 2011. Soil Quality Indicators.

28. SINGH S., SINGH J., SINGH N. Studies on the impact of fluoride toxicity on growth parameters of Raphanus sativus L. Indian Journal of Scientific Research, 4 (1), 61, 2013.

29. IRAM A., KHAN T.I. Effect of sodium fluoride on seed germination, seedling growth and biochemistry of Abelmoschus esculentus. Journal of Plant Biochemistry \& Physiology, 1, 2016.

30. PATIL S.B., BODHE S.K. Image processing method to measure sugarcane leaf area. International Journal of Engineering Science and Technology, 3 (8), 6394, 2011.

31. AYOLAGHA G., PETER K. Effect of remediation on growth parameters, grain and dry matter yield of soybean (Glycine max) in crude oil polluted ultisols in Ogoni Land, South Eastern Nigeria. African Journal of Environmental Science and Technology, 7(2), 61, 2013.

32. ARNON D.I., Copper enzymes in isolated chloroplasts. Polyphenoloxidase in Beta vulgaris. Plant Physiology, 24 (1), 1, 1949.

33. KIRK J., ALLEN R. Dependence of chloroplast pigment synthesis on protein synthesis: effect of actidione. Biochemical and Biophysical Research Communications, 21 (6), 523, 1965. 
34. REISS C., Measuring the amount of ascorbic acid in cabbage. Tested studies for laboratory teaching, 7, 8, 1993.

35. CHEN J., SHIYAB S., HAN F.X., MONTS D.L., WAGGONER C.A., YANG Z., SU Y. Bioaccumulation and physiological effects of mercury in Pterisávittata and Nephrolepisáexaltata. Ecotoxicology, 18 (1), 110, 2009.

36. MALAR S., MANIKANDAN R., FAVAS P.J., SAHI S.V., VENKATACHALAM P., Effect of lead on phytotoxicity, growth, biochemical alterations and its role on genomic template stability in Sesbania grandiflora: a potential plant for phytoremediation. Ecotoxicology and environmental safety, 108, 249, 2014.

37. FORNASIERO R.B. Fluorides effects on Hypericum Perforatum plants: first field observations. Plant Science, 165 (3), 507, 2003.

38. ALIM H., AHMAD M.A., MUNIR I., KHAN I., MUSTAFA G., ULLAH I., KHAN I. The effect of different concentrations of the fluoride ion on the growth and nutritional value of two elite genotypes of Triticum Aestivum. Fluoride, 50 (1), 143, 2017.

39. SINGH G., KUMARI B., SINAM G., KUMAR N., MALLICK S. Fluoride distribution and contamination in the water, soil and plants continuum and its remedial technologies, an Indian perspective - a review. Environmental Pollution, 239, 95, 2018.

40. PAPAFOTIOU M., PERGIALIOTI N., TASSOULA L., MASSAS I., KARGAS G. Growth of native aromatic xerophytes in an extensive Mediterranean green roof as affected by substrate type and depth and irrigation frequency. Hort Science, 48 (10), 1327, 2013.

41. SREEDEVI R., DAMODHARAM T. Asian Journal of Plant Science and Research, 3 (2), 38, 2013.

42. YAMAUCHI T., FUJISAWA H. Purification and Cahracyterization of te Brain Calmodulin-Dependent Protein Kinase (Kinase II), Which Is involved in the Activation of Tryptophan 5-Monooxygnase. European journal of biochemistry, 132 (1), 15, 1983
43. GOMATHI R., RAKKIYAPAN P. Comparative lipid peroxidation, leaf membrane thermostability, and antioxidant system in four sugarcane genotypes differing in salt tolerance. International Journal of Plant Physiology and Biochemistry, 3 (4), 67, 2011.

44. CHAKRABARTI S., PATRA P.K. Biochemical and antioxidant responses of paddy (Oryza sativa L.) to fluoride stress. Fluoride, 48 (1), 56, 2015.

45. KHAN T., MAZID M., MOHAMMAD F. A review of ascorbic acid potentialities against oxidative stress induced in plants. Journal of Agrobiology, 28 (2), 97, 2011.

46. KEYVAN S., The effects of drought stress on yield, relative water content, proline, soluble carbohydrates and chlorophyll of bread wheat cultivars. J. Anim. Plant Sci. 8 (3), 1051, 2010.

47. ZOUARI M., AHMED C.B., ELLOUMI N., ROUINA B.B., LABROUSSE P., ABDALLAH F.B. Effects of irrigation water fluoride on relative water content, photosynthetic activity, and proline accumulation in young olive trees (Olea Europaea L. Cv Chemlali) in arid zones. Fluoride. 49 (3), 366, 2016.

48. NANDWAL A., GODARA M., SHEOKAND S., KAMBOJ D.V., KUNDU B.S., KUHAD M.S., KUMAR B., SHARMA S.K., Salinity-induced changes in plant water status, nodule functioning, and ionic distribution in phenotypically differing genotypes of Vigna radiata $\mathrm{L}$. Journal of plant physiology, 156 (3), 350, 2000.

49. GARG N., SINGLA R. Variability in the response of chickpea cultivars to short-term salinity, in terms of water retention capacity, membrane permeability, and osmoprotection. Turkish Journal of Agriculture and Forestry, 33 (1), 57, 2009.

50. KAKAR S.R., WAHID A., TAREEN R.B., KAKAR S.A., TARIQ M., KAYANI S.A. Impact of municipal waste water of Quetta city on biomass, physiology, and yield of canola (Brassica napus L.). Pak. J. Bot, 42 (1), 317, 2010. 